\title{
GLADIADORES NA ROMA ANTIGA: DOS COMBATES ÀS PAIXÕES COTIDIANAS
}

\author{
Gladiators in Ancient Rome: from battles \\ to every day passions
}

Lourdes Conde Feitosa*

GARRAFFONI, R. S. Gladiadores na Roma Antiga: dos combates às paixões cotidianas. São Paulo: Annablume/Fapesp, 2005, 225 p.

Gladiadores na Roma Antiga, livro da historiadora e arqueóloga Renata Senna Garraffoni, apresenta ao público brasileiro inovadoras reflexões sobre um tema muito presente no imaginário moderno: o universo da gladiatura romana. Resultado de diversos anos de intensa pesquisa, a análise da autora se insere no campo das novas abordagens teóricometodológicas que realçam o conhecimento histórico como resultado de discursos que são influenciados por conceitos, valores e concepções que variam segundo o lugar e tempo histórico em que são formulados, em desenvolvimento no exterior nas últimas três décadas, e no Brasil nos últimos dez anos.

Ao partir dessa relação entre a Antiguidade e o mundo contemporâneo na escrita da História Antiga, Garraffoni estabelece um diálogo com a produção historiografia dos séculos XIX e XX, a fim de identificar as imagens construídas a respeito dos gladiadores e das lutas gladiatoriais para a sociedade romana. Inquieta com as interpretações que, em sua imensa maioria, apresentam os combates como um fenômeno único e homogêneo, relacionados ora a uma "política do pão e do circo", ora ao processo de "romanização", propõe-se a analisar as complexas redes de relações que se estabeleciam para que os espetáculos pudessem acontecer, bem como os

* Doutora em História Cultural. Pesquisadora Associada ao NEE e CPA, ambos da Unicamp. 
vínculos cotidianos dos gladiadores com os espetáculos e a sua receptividade nas camadas populares romanas.

Diante da dimensão territorial e de sua grande diversidade cultural, econômica, religiosa e social, a análise da autora centra-se no Ocidente Romano, em particular em Roma, Pompéia e a região da Hispânia, no decorrer do primeiro século d.C., e é realizada a partir de documentos literários e uma gama de material arqueológico como relevos funerários, pinturas de paredes e estruturas de anfiteatros.

Em uma interpretação dinâmica e plural, é ressaltada a complexa diversidade dos espetáculos, organizados tanto pelo poder público, os munera oficiais, como por pessoas de posses, suscitados a partir de motivações que iam do aspecto político, militar, econômico, de entretenimento, ao religioso, em homenagem a um ilustre falecido. Há a preocupação em mostrar a flexibilidade das estruturas montadas, feitas em madeira ou pedras, preparadas para a execução de espetáculos variados como, por exemplo, as naumáquias, os combates e as caçadas. Com essa análise arqueológica, a autora destaca as diferentes composições dos edifícios e realça o quanto a topografia, os gostos da população local, as condições econômicas, entre outros, expressavam valores culturais que influenciavam na organização e no sucesso do evento programado. Também o espaço interno dos anfiteatros é destacado em sua dinâmica de congregar interesses, opiniões, desejos e conflitos de seu público, reflexo de uma leitura ativa da sociedade romana, na qual se evidenciam visões variadas de mundo.

Essa interpretação da sociedade como um espaço sociocultural complexo e heterogêneo também levou a estudiosa a perceber variadas acepções dos combates de gladiadores. Por meio da contraposição de relevos funerários de membros da elite romana com grafites parietais, escritos por populares, ficou evidente que os primeiros exprimem um desejo em manter viva a memória daqueles que haviam propiciado o espetáculo, ao destacar no relevo a grandiosidade da festa, a numerosa quantidade de gladiadores e a diversidade de lutas ocorridas, enquanto os grafites têm a sua ênfase no cotidiano do gladiador, em suas habilidades, treinos e lutas, vitórias e derrotas, e em suas relações familiares e de amizade.

Ao discutir a condição de infâmia atribuída ao gladiador pela maioria dos autores modernos, que o fazem baseados em textos aristocráticos romanos, Garraffoni enfatiza o quanto esse adjetivo está imbuído de 
conotação pejorativa. Em sua análise a respeito do vocábulo latino infamia, verifica que, em geral, era utilizado na legislação romana para designar pessoas desonradas e um indivíduo adquiria essa designação ao ser punido por determinados crimes como roubo, injúria, bigamia, usura, entre outros. A punição variava segundo o status jurídico do transgressor, indo desde multas, perda dos direitos políticos e o exílio - para cidadãos - e castigos físicos, encarceramento e até a morte - para os não cidadãos. Além dos crimes, percebe que também algumas profissões eram taxadas de infames como, por exemplo, proprietários de hospedarias, atores e gladiadores, o que lhes resultava em restrições jurídicas e políticas. Desta maneira, conclui a autora que esse significado depreciativo atribuído a uma série de profissões sugere que a infamia representava um tipo de censura moral a determinadas ações e modos de vida, em particular aqueles considerados indignos às elites aristocráticas romanas.

Por discordar da caracterização do gladiador como um degredado social, que buscava na arena o resgate de sua fama perdida, a pesquisadora buscou outras possíveis representações dessa atividade em ambiente popular. Com a análise das inscrições sobre os combatentes, pôde verificar que durante o século I d.C. os ludi passaram a ser exercidos não só por escravos, criminosos ou prisioneiros de guerras, mas também por mulheres e muitos auctorati, pessoas que vendiam, por um tempo determinado, sua liberdade para poder estar na gladiatura. Igualmente, notou uma profissionalização desta atividade, um orgulho por ela e por seus praticantes. Mensagens registradas pelas amadas, por amigos e colegas de ofício que buscavam preservar uma imagem positiva do falecido, os seus feitos, suas habilidades, paixões, conquistas e popularidade, o que indica, segundo Garraffoni, que a pecha de infame perdia a sua conotação em ambiente popular.

O uso do documento antigo na língua original em que foi escrito, o latim, permitiu à pesquisadora discutir e propor interpretações a partir das próprias fontes. Tendo claro que a investigação histórica não é feita apenas por meio da documentação escrita, mas também pela interpretação das fontes materiais, a conciliação entre História e Arqueologia possibilitou à autora ampliar a investigação sobre o universo gladiatorial, destacando o seu perfil humano, suas relações afetivas, de amizade e a sua integração no ambiente popular, que lhe foi valioso para questionar e ampliar as informações expressas em textos literárias aristocráticos. 
A opção metodológica adotada para o trabalho com o material arqueológico, como os cuidados com o exame das inscrições, a percepção de suas particularidades e a influência dos estudiosos modernos nas sugestões de leituras dos textos fragmentados, foi imprescindível para que a estudiosa trabalhasse com essa fonte material não como uma reprodução dos sentidos que continham ao ser escrita, mas como fruto de uma interpretação, que pode variar de um momento histórico a outro. Também a leitura de textos modernos em línguas estrangeiras possibilitou que Garraffoni, como historiadora da Antiguidade, pudesse acompanhar as discussões e teses apresentadas sobre o assunto.

Considerar a História como discurso propiciou à autora o exame dos diversos modelos interpretativos construídos sobre as lutas gladiatoriais, muitas vezes considerados como o próprio resgate do passado. Aliado a isso, o uso de documentos literários e arqueológicos favoreceu à pesquisadora formular as suas próprias interpretações, questionar visões eurocentristas e colocar-se como uma construtora do conhecimento histórico, alargando o debate internacional a respeito dos combates. $\mathrm{O}$ grande mérito e inovação de Gladiadores na Roma Antiga estão em sua reflexão sobre a maneira de os gladiadores conceberem a vida, os combates e as suas relações em ambiente popular, indo além de estudos tradicionais, fundamentados no pensamento aristocrático, e contribuir para compreendermos a riqueza e a diversidade das relações sociais no mundo romano antigo. Além de ser um texto bem escrito de um tema fascinante, é um excelente exemplo de como é legítima e justificável a pesquisa em História Antiga fora dos territórios onde viveram os povos antigos. 